\title{
Disturbances and Biodiversity at Grafenwöhr Training Area
}

\author{
Martin Alt, Anke Jentsch, Constanze Buhk \& Manuel Steinbauer
}

\begin{abstract}
Disturbance ecology, namely the interaction of natural and anthropogenic disturbance with distribution, composition and richness of biotic units is the focus of this vegetation survey. Data on presence-absence of plant species were recorded in 100 equidistant quadratic units of one hectare size covering an area of $4 \times 4 \mathrm{~km}^{2}$. Each unit is subdivided in relevés with a similar disturbance regime enabling a spatial quantification of different disturbance agents. Disturbance types are not only measured qualitatively but assessed quantitatively (frequency, seasonality, duration, size, form, distribution, selectivity). We conducted several equally designed studies in central Europe (Franconian Jura, Fichtelgebige, Grafenwöhr, Elbe). Comparable data are also available for sites in Namibia, Morocco, Sweden, Ethiopia and Bangladesh. The Grafenwöhr sample site is situated within a military training area (32U 694000E 5508300N). The area is characterized by grassland (38\%), forest (34\%), and fallow land (21\%) and is located between 440 and $560 \mathrm{~m}$ a.s.1.. Bedrock consists of Upper Cretaceous, Malm and Dogger. The mean annual temperature is $7.5^{\circ} \mathrm{C}$ and the annual precipitation averages $700 \mathrm{~mm} / \mathrm{yr}$ (climate station Eschenbach). The site is maintained in a semi-natural state and is inhabited by large populations of deer and wild boar with annual mowing and some forestry management. Dominating land use is military training such as driving tanks, military manoeuvres or excavations. Overall number of recorded plant species is 654 . This report describes the available content in the vegetation-plot database Disturbances and Biodiversity at Grafenwöhr Training Area (GIVD ID EU-DE-025).
\end{abstract}

Keywords: agriculture; cultural landscape; disturbance ecology; heterogeneity; military training area; pattern; plant diversity; vegetation.

\section{Disturbances and Biodiversity at Grafenwöhr Training Area}

Scope: Database of vegetation (presence/absence) and disturbance data (type of disturbance, frequency, duration, seasonality, size, form distribution, selectivity). In a study area of 4 x 4km 100 systematically arranged $100 \times 100$ m plots were divided into 595 subplots (at least 10 m²) representing land use and disturbance regime.

Status: completed and continuing Period: 2008-2008

Database manager(s): Martin Alt (alt@uni-landau.de); Anke Jentsch (anke.jentsch@uni-bayreuth.de)

Owner: [NA]

Web address: [NA]

Availability: according to a specific agreement

Database format(s): MS Access

Online upload: no Online search: [NA]

Export format(s): MS Access, Excel, Open Document, CSV file, plain text file

Publication: [NA]

Plot type(s): normal plots

Non-overlapping plots: 595

Total plot observations: 595

Plot-size range: $15.3-10,000 \mathrm{~m}^{2}$

Countries: DE: $100.0 \%$

Forest: [NA] — Non-forest: [NA]

Guilds: all vascular plants: $100 \%$

Environmental data: other soil attributes: $100 \%$

Performance measure(s): presence/absence only: $100 \%$

Geographic localisation: [NA]

Sampling periods: $2000-2009: 100.0 \%$

Information as of 2012-07-12; further details and future updates available from http://www.givd.info/ID/EU-DE-025

Martin Alt* (alt@uni-landau.de), Constanze Buhk (buhk@uni-landau.de)

Institut für Umweltwissenschaften, Universität Koblenz - Landau, Fortstr. 7, 76829 Landau, GERMANY

Anke Jentsch (anke.jentsch@uni-bayreuth.de), Manuel Steinbauer (manuel.steinbauer@uni-bayreuth.de)

BayCEER, Universität Bayreuth, Dr. Hans-Frisch-Str. 1-3, 95448 Bayreuth, GERMANY

*Corresponding author 